Vol. 9 (2000): 71-77.

Research Note

\title{
Estimation of soil nitrate in the spring as a basis for adjustment of nitrogen fertiliser rates
}

\author{
Jouko Sippola \\ Agricultural Research Centre of Finland, Resource Management Research, Environmental Resources, \\ FIN-31600 Jokioinen, e-mail:jouko.sippola@mtt.fi
}

\begin{abstract}
The performance of SOILN model, which simulates soil nitrogen dynamics, was evaluated in respect to its ability to predict nitrate content in soil in spring when growing barley. The data obtained in three year nitrogen fertiliser experiments on different soil types was used. Model was parametrised using the data of the first experimental year and validation results obtained in following years are presented. The results of the simulations of the springtime nitrate in the root zone showed a reasonably small deviation from the measured values. The coefficient of determination, $R^{2}=0.56$ was significant. The regression equation was $y=4+0.66 \mathrm{x}$ where the constant term was not significantly different from zero and the slope deviated from zero. The mean value of measured nitrate in the root zone in spring was $16 \mathrm{~kg} / \mathrm{ha}$ and that from the simulation was $15 \mathrm{~kg} / \mathrm{h}$ a showing that the mean values were close to each other. The mean of deviations between measured and simulated values was $4 \mathrm{~kg} / \mathrm{ha}$ and the maximum deviation $9 \mathrm{~kg} / \mathrm{ha}$. It is concluded that simulation estimated springtime soil nitrate concentration with reasonable confidence that further testing of estimating soil nitrate concentration in spring for adjustment of nitrogen fertilisation using SOILN model should be continued.
\end{abstract}

Key words: simulation models, nitrate nitrogen, nitrogen fertilisers, barley

\section{Introduction}

Nitrogen is the plant nutrient which has the greatest influence on crop yield. Because of the importance of nitrogen there is an urgent need for soil test methods to optimise fertiliser applications. This is not only for economy in nitrogen use, but also to minimise the risk of leaching of nitrate to surface- and groundwater. In Central Europe the so called Nmin-method is used to analyse soil mineral nitrogen and to adjust nitrogen fertilisation accordingly (Wehrman and Scharpf 1979). In a previous study this method did not prove to be useful in Finnish conditions when growing cereals following cereals, but in other types of crop rotation mineral nitrogen may continue to accumulate (Sippola and Yläranta 1985). From a practical point of view, the time span during which it is possible to sample soil before sowing is very limited in Finland because of soil freezing and this means that a method 


\section{AGRICULTURAL AND FOOD SCIENCE IN FINLAND}

\section{Sippola, J. Estimation of soil nitrate as a basis for adjustment of nitrogen fertiliser rates}

based on soil sampling in spring is not feasible.

The SOILN simulation model has been developed to describe nitrogen dynamics in the soil (Johnsson et al. 1987). The use of simulation to estimate the springtime mineral nitrogen content, taking account of the depleted situation at harvest and the climatic conditions which follows could, if applicable, provide a fast way to obtain information for adjusting basic nitrogen fertiliser recommendations according to the actual requirement.

The objective of this investigation was to find out if it is possible by using the SOILN model and weather data from outside the cropping season to predict the soil nitrate content which could be used as a substitute for measured nitrate levels for optimising nitrogen fertiliser application rates.

\section{Material and methods}

The experimental data used to calibrate and validate the SOIL and SOILN models were obtained from 11 nitrogen fertilisation experiments with barley carried out during 1981-1990 in research stations of the Agricultural Research Centre of Finland. Details of soil properties and yield data have been published previously (Sippola and Yläranta 1985, Lindén et al. 1992, Kätterer et al. 1999). Heavy clay, sandy clay, silty clay and fine sand soils were represented. Soils were sampled in three layers to 60 or $70 \mathrm{~cm}$ depth early in spring before sowing and in autumn after harvest for nitrate and moisture contents. In some of the experiments a monthly sampling interval was adopted. An additional soil sampling in spring following the third experimental year was made to gather more data for validation. Barley was the experimental crop and data obtained from 80 or $90 \mathrm{~kg} / \mathrm{ha}$ nitrogen treatments were used in this study. Temperature and rainfall data were obtained from weather stations located at each Experimental Station. Only for these two driving variables daily data was needed when the
CNUMD $=-1$ option of the SOIL model was used (Jansson 1991). For wind speed, humidity and cloudiness an average value on each site was taken.

The soil hydraulic properties required by the SOIL model were obtained using the PLOTPF program and soil texture and organic matter data at each site (Jansson 1989). Soil moisture determined in laboratory was used to check the success of simulations when SOIL model parameters were adjusted. In addition to the soil hydraulic properties, soil moisture values were rather sensitive to parameters describing maximum root depth and critical tension for reduction of water uptake. Their optimised values depending on soil type ranged from -0.6 to -0.8 and from 200 to 2800 , respectively.

Parameters, such as organic carbon and total nitrogen, used in the SOILN model were obtained by soil analysis (Jansson et al. 1991). In addition, site specific values for $\mathrm{C} / \mathrm{N}$ ratio, initial values for ammonium and nitrate, for litter carbon and nitrogen, for humus carbon and nitrogen, based on samples collected before the start of the experiment were used. Results of the first of the three experimental years were used when parameter values were adjusted to give proper results for each site. Simulation results for yield and nitrogen uptake of grain and straw in addition to soil nitrate concentrations were compared with measured data when parameters were adjusted to improve agreement. The parameter for radiation use efficiency (PHOEFF) was used to adjust yield level and it ranged from 1.5 to 2.2 in different experimental sites. The distribution of accumulated biomass between straw and grain was adjusted with parameter AGRAIN which ranged from 0.016 to 0.025 . Several parameters describing soil organic matter flows were adjusted to be site specific to improve the agreement between simulated and measured nitrate values. Their ranged as follows: CNORG (carbon-nitrogen ratio of microorganisms and humified products) 10-14, HUMK (humus mineralisation rate) 0.00002-0.00015, LITEFF (efficiency of the internal synthesis in litter) $0.2-0.7$, LITHF (litter carbon humification fraction) 0.2 
Vol. 9 (2000): 71-77.

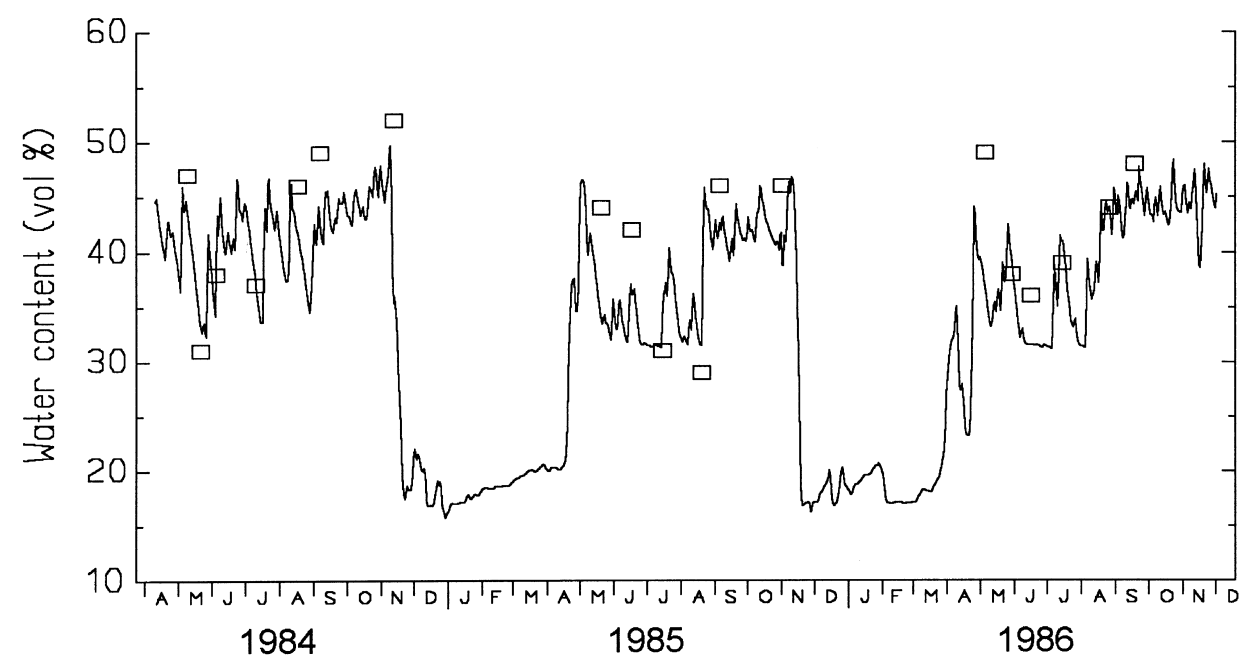

Fig. 1. Measured (squares) and simulated moisture contents in plogh layer of a clay soil in Jokioinen.

0.8, LITK (litter decomposition rate) 0.02-0.035, DENPOT (potential rate of denitrification) $0.02-$ 0.12 , DFRAC1 (fraction of potential denitrification in plough layer) 0.2-0.6, UPMA (fraction of mineral nitrogen available for immobilisation and plant uptake) $0.04-0.08$. However, many of the model parameters were those standard values provided with the program and found valid in Swedish conditions (Jansson et al. 1991). A more thorough site specific parametrisation was not pursued because the aim of the study was to test if the SOILN model could be useful in the situations where site and soil properties are known only rather generally. Finally, the results of the second and third years were used to evaluate the validity of the simulation results.

\section{Results and discussion}

\section{Moisture contents predicted by the SOIL model}

The results of the simulated soil moisture contents for the clay soil in Jokioinen show that the simulated values in the surface layers follow the drying out of the soil in summer and increase in moisture content following autumn rains, but periodical sampling does not adequately describe the total picture (Fig. 1). Figure 2 indicate that, according to regression model, $58 \%$ of measured variation in soil moisture in the plough layer of a silty clay is explained by simulated values. The constant term in the regression equation deviates to a quite large degree from zero, and the slope is much less than one. Because soil

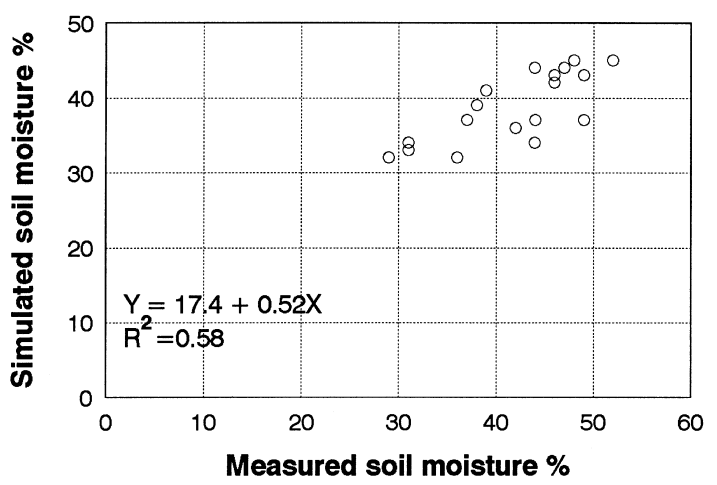

Fig. 2. Comparison between measured and simulated moisture contents in plogh layer of a clay soil in Jokioinen. 
Sippola, J. Estimation of soil nitrate as a basis for adjustment of nitrogen fertiliser rates

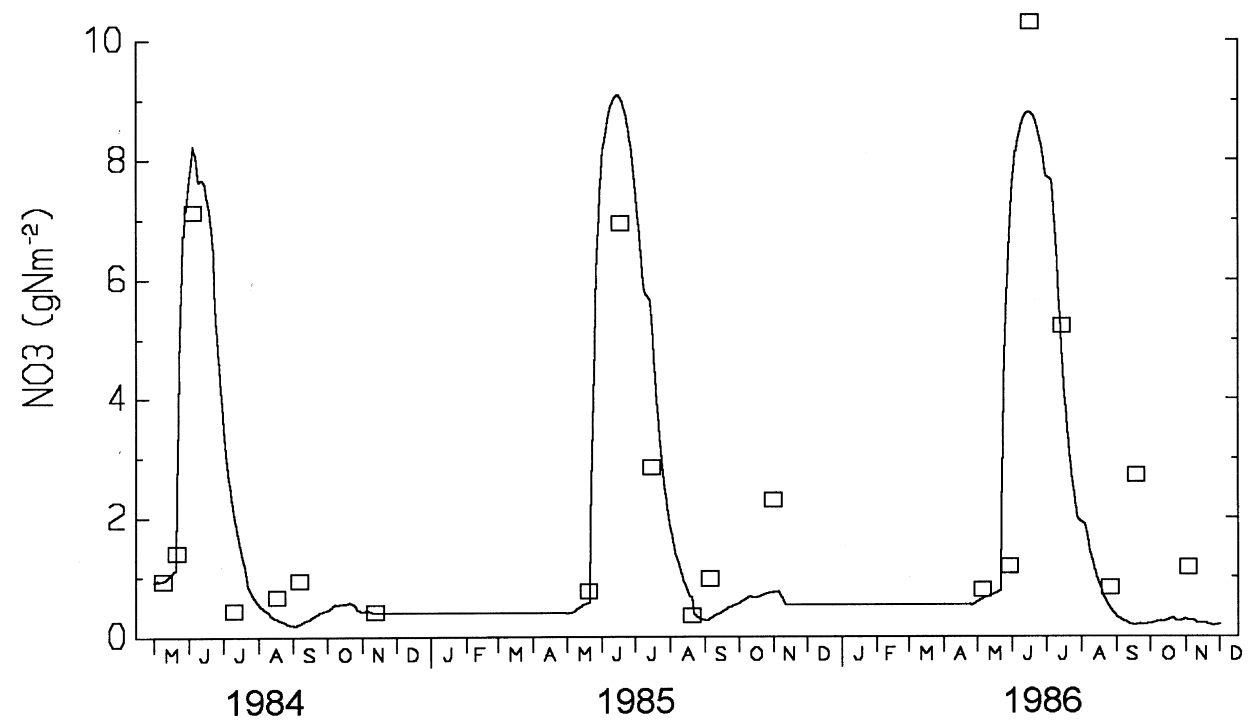

Fig. 3. Measured (squares) and simulated nitrate concentrations in plogh layer of a clay soil in Jokioinen.

water flows are used as driving variables in the SOILN model, a good agreement between simulated and measured values is required. Deviations of the results of the SOIL model from measured values decreases the reliability of simulated nitrate estimates.

\section{Nitrate concentrations predicted by SOILN model}

As shown in Figure 3, the nitrate concentration of the plough layer in the clay soil at Jokioinen follows the increase caused by fertiliser application, but in 1985 the measured value is low and 1986 high compared to the simulated value. Crop uptake decreases the soil nitrate concentration effectively, and at harvest concentrations are low similar to those at spring. Simulations follow the measured values closely at this stage. Later in autumn, there is some accumulation of nitrate in soil which simulations do not follow, predicting lower concentrations in both years. In winter when soil is frozen, there is no change in the simulated nitrate concentration. The ac- cumulated nitrate shown by measured values have decreased by spring to a similar low level what simulation predicted.

In opposite to the clay soil, in the fine sand soil at Peipohja the simulation predicted more mineralisation during late autumn than what was shown by measurement (Fig. 4). However, in the spring the simulated values were in good agreement with the measured values which ranged from 3.5 to $11.2 \mathrm{~kg} / \mathrm{ha}$ in the $20 \mathrm{~cm}$ plough layer. This because nitrate losses due to leaching are clearly simulated in the porous find sand soil in late autumn and early spring.

Generally, the small number of measured data available for parameter derivation had its restrictions in arriving at optimal parameter values. This was indicated by values for different layers deviating occasionally quite considerably. Low nitrate concentration in deeper layers did not change the total content in root zone to a great deal, however.

The results of the simulations of the springtime nitrate in the root zone at 11 sites show a reasonable small variation from the measured values (Fig. 5). The coefficient of determination, $\mathrm{R}^{2}=0.56$ is significant. The slope of the regres- 
Vol. 9 (2000): 71-77.

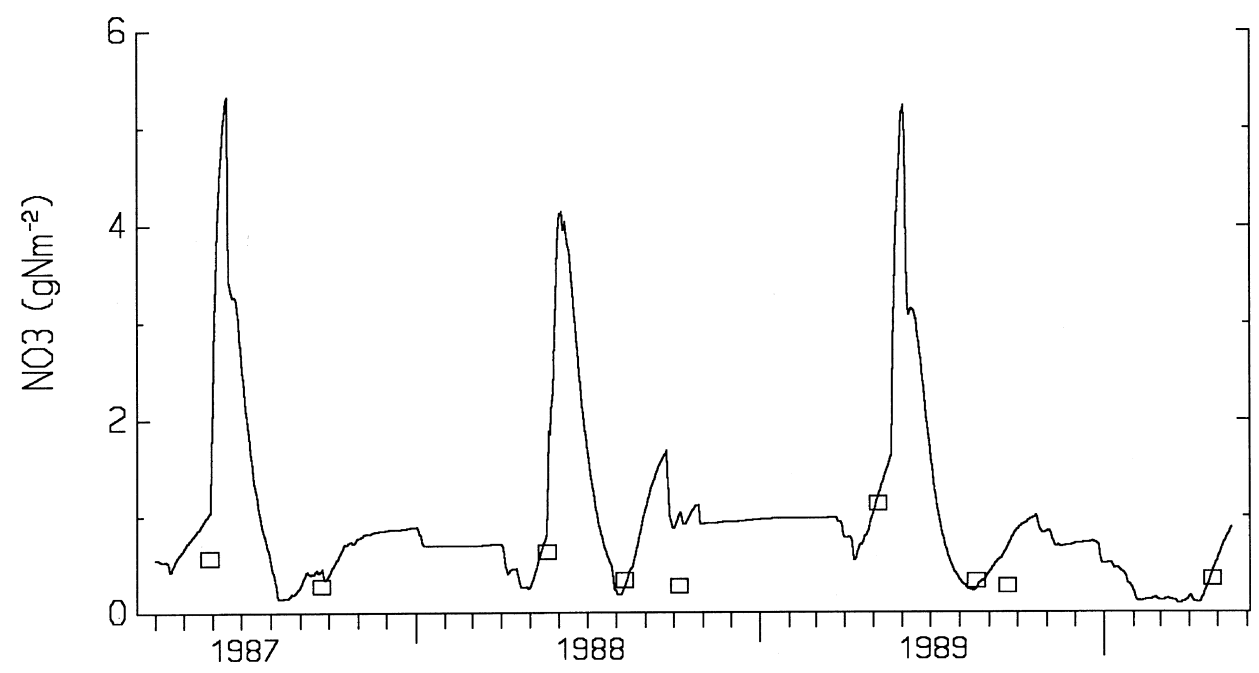

Fig. 4. Measured (squares) and simulated nitrate concentrations in plogh layer of a fine sand soil in Peipohja.

sion equation is less than one indicating also deviation from a perfect agreement. When comparing measured and simulated soil mineral nitrogen in spring in winter wheat trials in United Kingdom Whitmore and Addiscott found a much higher regression coefficient 0.947 (Whitmore and Addiscott 1985). However, the correlation coefficient $r=0.78$ was of the order found in the present study.

The mean value of measured nitrate in spring was $16 \mathrm{~kg} / \mathrm{ha}$ and that of the simulated $15 \mathrm{~kg} / \mathrm{ha}$ showing that mean values were close together (Table 1). The mean of deviations between measured and simulated values was $4 \mathrm{~kg} / \mathrm{ha}$, and the maximum deviation $9 \mathrm{~kg} / \mathrm{ha}$. From a practical point of view, deviations of less than $10 \mathrm{~kg} / \mathrm{ha}$ are not of importance, and also errors in determining soil mineral nitrogen may be even larger due to soil variability (Otter-Nacke and Kuhlman 1991). Compared to results obtained in the current study Otter-Nacke and Kuhlman found spring mineral nitrogen values that were clearly higher than in the present study. The deviation between measured and simulated mineral nitrogen contents ranged from 14 to $19 \mathrm{~kg} / \mathrm{h}$. They concluded that these values deviate too much to

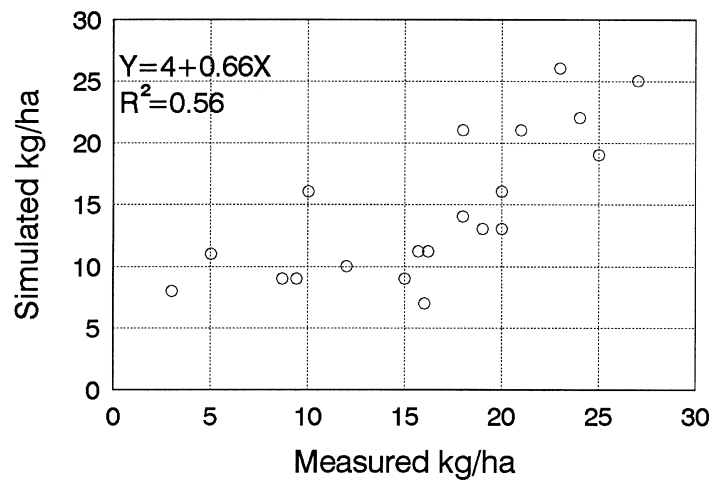

Fig. 5. Comparison between measured and simulated root zone nitrate content in spring. Results from 11 sites with various soil types, one or two observations each.

Table 1. Soil nitrate in spring before sowing in root zone $\mathrm{kg} / \mathrm{ha}$. 11 sites over 1 or 2 years during 1983-90. $\mathrm{N}=20$.

\begin{tabular}{lccc}
\hline & Measured & Simulated & Difference \\
\hline Mean & 16 & 15 & 4 \\
Standard error & 1.5 & 1.3 & 0.6 \\
Standard deviation & 6.6 & 5.9 & 2.5 \\
Minimum & 3 & 7 & 0 \\
Maximum & 27 & 26 & 9 \\
\hline
\end{tabular}




\section{AGRICULTURAL AND FOOD SCIENCE IN FINLAND}

Sippola, J. Estimation of soil nitrate as a basis for adjustment of nitrogen fertiliser rates

be used with any confidence as an aid when making nitrogen fertiliser recommendations. When testing the DAISY model, Jensen et al. (1996) observed a somewhat closer agreement between measured and simulated mineral nitrogen values, with a mean difference of $11 \mathrm{~kg} / \mathrm{ha}$ for a large number of observations. However, they concluded that results deviated too much to be used as tool in fertiliser recommendations.

Based on the results of the present study, it may be concluded that deviations of simulated from measured values are sufficiently small that further testing of the SOILN model for estimating soil nitrate concentration in spring as a basis for adjustment of nitrogen fertiliser application should continue. Tests should include recommendations for practical scale farming and evaluation of the results obtained.

Acknowledgements. The financial support for the project by The Academy of Finland and Nordic Council of Ministers (NMR) is gratefully acknowledged.

\section{References}

Jansson, P.-E. 1989. Manual and help library for PLOTPF. Swedish University of Agricultural Sciences, Dept. of Soil Sciences, Mimeogr. 7 p.

- 1991. SOIL model. User's manual. Swedish University of Agricultural Sciences, Dept. of Soil Sciences, Communications 91: 7.

-, Eckersten, H. \& Johnsson, H. 1991. SOILN model. User's manual. Swedish University of Agricultural Sciences, Dept. of Soil Sciences, Communications 91: 6.

Johnsson, H., Bergström, L., Jansson, P.-E. \& Paustian, K. 1987. Simulated nitrogen dynamics and losses in a layered agricultural soil. Agriculture, Ecosystems and Environment 18: 333-356.

Jensen, C., Stougaard, B. \& Ostergaard, H. 1996. The performance of the Danish simulation model DAISY in prediction of Nmin at spring. Fertilizer Research 44: 79-85.

Kätterer, T., Heidman, T., Sippola, J., Haugen, L.E., Borg, G.C., Haraldsen, T.K. \& Blombäck, K. 1999. Agricultural experimental sites. In: Nitrogen processes in arable and forest soils in the Nordic countries. Field scale modelling and experiments. ThemaNord 1999: 560. p. 41-52.

Lindén, B., Lyngstad, I., Sippola, J., Soegaard, K. \& Kjellerup, V. 1992. Nitrogen mineralization during the growing season. Swedish Journal of Agricultural Research 22: 3-12.

Otter-Nacke, S. \& Kuhlmann, H. 1991. A comparison of the performance of $\mathrm{N}$ simulation models in the prediction of Nmin on farmers' fields in the spring. Fertilizer Research 27: 341-347.

Sippola, J. \& Yläranta, T. 1985. Mineral nitrogen reserves in soil and nitrogen fertilization of barley. Annales Agriculturae Fenniae 24: 117-124.

Wehrman, J.G. \& Scharpf, H.C. 1979. Der Mineralstickstoffgehalt des Bodens als Massstab für den Stickstoffdüngerbedarf (Nmin-Methode). Plant and Soil 52: 109-126.

Whitmore, A.P. \& Addiscott, T.M. 1985. Computer simulation of changes in soil nitrogen during under a crop of winter wheat. In: Neeteson, J.J. \& Diltz, K. (eds.). Assesment of nitrogen fertilizer requirement. Haren: Institute for Soil Fertility. p. 133-137. 
Vol. 9 (2000): 71-77.

\title{
SELOSTUS
}

\section{Maassa olevan nitraattitypen arviointi simulointimallin avulla}

\author{
Jouko Sippola \\ Maatalouden tutkimuskeskus
}

Typpi on kasvinravinne, joka ratkaisevimmin vaikuttaa satoon. Typelle ei kuitenkaan ole käytössä yleistä viljavuusanalyysimenetelmää kuten muille ravinteille. Menetelmä olisi hyvin tarpeellinen typpilannoituksen optimoimiseksi taloudellisuuden ja ympäristövaikutusten suhteen. Keski-Euroopassa maasta määritetään mineraalityppi keväällä ennen lannoitusta. Meillä menetelmä on epäkäytännöllinen, koska roudan sulamisen ja kylvöjen välinen aika on lyhyt. Simulointimallin käyttö kevään mineraalityppimäärän arvioimiseen talven ja varhaiskevään sääolojen sekä maan ominaisuuksien perusteella on yksi mahdollisuus. Tutkimuksessa selvitettiin SOILN simulointimallin kykyä ennakoida kevään nitraattityppi ohran typpilannoituskokeiden aineistoissa, joissa maan mineraalityppi oli määritetty. Kokeita oli kaik- kiaan 11 Maatalouden tutkimuskeskuksen eri tutkimusasemilla vuosina 1981-1990.

Tulosten mukaan simulaatiomalli ennusti juuristovyöhykkeen nitraatin määrän kohtuullisella tarkkuudella. Kaikkien kokeiden nitraattipitoisuuden mitattu keskiarvo oli $16 \mathrm{~kg} / \mathrm{ha}$ ja simulointien vastaava keskiarvo $15 \mathrm{~kg} / \mathrm{ha}$. Mitattujen ja simuloitujen arvojen suurin poikkeama oli $9 \mathrm{~kg} / \mathrm{ha}$ ja keskimääräinen poikkeama $4 \mathrm{~kg} / \mathrm{ha}$. Siten poikkeama on käytännön lannoitustarkkuutta ajatellen riittävän pieni, jotta menetelmän hyödyllisyyden tarkastelua on perusteltua jatkaa. Tällöin tarkasteluun tulee ottaa mukaan typpilannoitussuositusten teko käytännön viljelyksille ja tilanteisiin, jossa on käytetty eloperäisiä lannoitteita. 